\title{
What elements of financial stress affect contracting out and intermunicipal cooperation in the provision of local public services? The impact of the great recession
}

\author{
José Luis Zafra Gómez \\ University of Granada \\ Juan Sánchez Fernández \\ University of Granada \\ Ana María Plata Díaz \\ University of Granada \\ Gemma Pérez López \\ University of Granada
}

Received April 8, 2014; accepted September 5, 2014.

\begin{abstract}
The current financial crisis is one of the main factors underlying proposals made for change delivery form of municipal services. However, this situation is affected by a wide variety of financial indicators, and it is necessary to determine which of these indicators have greatest influence on decisions regarding outsourcing or long-term inter-municipal cooperation. Furthermore, the Great Recession could have modified these financial indicators, and so we must identify which of them impacted on public-service outsourcing and/or cooperation both before and during the crisis. This paper evaluates these factors with respect to a sample of Spanish municipalities, for the periods 2002-2007 and 20082010 , via a discriminant analysis. The results obtained show that the financial indicators that affect outsourcing and cooperation are different, specifically, we find that the variables which are related to spending on transfers, budget sustainability and the flexibility of the entity, measured by its outstanding debt have the greatest impact on the outsourcing process, while the cooperation processes are influenced, in addition to the latter factors, by the short-term solvency of the entity. The elements of short term solvency, flexibility and sustainability led municipalities to outsource their public services in the pre-crisis period, while only debt and financial independence influenced the cooperation decisions during the crisis period.
\end{abstract}




\section{KEYWORDS}

Financial stress, contracting out, intermunicipal cooperation, great recession, local government. 


\section{Introduction}

Fiscal stress is one of the explanatory factors most commonly referred to in studies of outsourcing and inter-municipal cooperation (Bel and Fageda, 2007). The reasoning used to relate the two concepts is based on the idea that municipalities in this situation are faced with falling revenues (transfers and/or taxes) and, not wishing to increase the local tax burden (Tiebout, 1956; Bel and Fageda, 2007), may choose to privatise public services that present a high degree of complexity and represent a significant cost to the local authority (Savas, 2000; Greene, 2002). Moreover, this situation has been aggravated by the current economic and financial crisis (Zafra-Gómez et al., 2009a, 2009b; Zullo, 2009). The effects of this crisis on public administration are reflected in a stricter control of budgets and deficits (López-Hernández et al., 2012) and this situation has prompted a search for solutions to fiscal stress, based primarily on recentralising the decision-making process and even on the use of new models of governance (Peters, 2011).

Among the options open to municipalities for alleviating situations of fiscal stress, one of the most common is to search for new forms of service delivery, such as privatisation (Moore, 1987; Hood, 1995). However, in recent years various alternatives to outsourcing - for example, inter-municipal cooperation - have arisen as a means of restructuring the delivery of public services (Mohr et al., 2010).

Nevertheless, empirical evidence is unclear as to whether situations of fiscal stress leading to outsourcing or inter-municipal cooperation are responsible for provoking changes in management attitudes (Levin and Tadelis, 2005; Bel and Fageda, 2007; Zullo, 2009). This may be due to the fact that most studies in this respect have been of a crosssectional nature, aiming to evaluate the performance of municipalities over an extended period of time (Bel et al., 2010). Moreover, as observed by Boyne (1998), the measures used to assess whether the municipality is undergoing fiscal stress are very poor and may not reflect the true situation (Brudney et al., 2005).

The use of long periods of analysis means that the circumstances characterising these periods must be taken into account. We are currently experiencing a period of global financial crisis, known as the Great Recession (GR), which is having a major impact on economic activity in both the private and the public sectors. Accordingly, the fiscal stress/outsourcing (or inter-municipal cooperation) relationship may have changed during this period. Authors such as James and Wooten (2006) and Maitlis and Sonenshein (2010) have reported that when an international crisis occurs, the structure and development of 
any organisation may be affected and undergo considerable change, and therefore action should be taken to overcome the problems faced (Christensen et al., 2011).

In view of this situation, it is necessary to identify the indicators that reflect the municipal financial situation, especially those with most impact on changes made in the provision of public services, and to determine whether these indicators are exerting the same influence during the GR.

Accordingly, the aim of this study is to establish whether the decisions taken by local public managers regarding outsourcing or inter-municipal cooperation are related to the presence of financial problems, specifically, when the municipality is undergoing a state of fiscal stress. This concept is distinguished from that of global financial crisis, known as the Great Recession (GR), which refers to the present global economic and financial crisis. The results obtained will clarify whether the financial variables were affected by the GR, thus impacting on how local public services are delivered, in terms of decisions to outsource or to enter into inter-municipal cooperation for this purpose. Furthermore, we consider a broad concept of fiscal stress, defining it in the framework of financial condition. In other words, we are not considering just the level of transfers or an indicator of local authority borrowing (Bel and Fageda, 2007), but also take into consideration variables related to transfers received, the fiscal capacity of the municipality, its cash position, level of debt and budget sustainability.

The rest of this paper is structured as follows. In the next section, the concept of financial condition is discussed, as a valuable element for measuring whether a municipality is undergoing financial stress. We then examine, from a theoretical standpoint, the relationship between fiscal stress and outsourcing or inter-municipal cooperation. Section four introduces the concept of crisis management to address the implications of the impact of the GR on the relationship being studied. In section five, we explain the methodology used, the data analysed and the results obtained, for a sample of Spanish municipalities for the period 2002-2010. In the final section, we discuss these results and draw appropriate conclusions. 


\section{Using financial condition to measure fiscal stress in local government}

The primary objective of financial information in the context of local government is to represent its economic and financial position, thus facilitating decision-taking by individuals, rating agencies, managers and the community in general, providing an instrument for effective action to be taken when financial circumstances are adverse, and a measure for determining rewards when circumstances are favourable. One of the main lines of research currently being addressed in the area of local government finance is the construction and development of indicators to measure how local authorities are managing their resources and their finances.

Studies related to the financial position of an entity have referred to the concept of financial position, i.e., the entity's ability to meet its obligations from the resources at its disposal (Lorig, 1941; Berne, 1992; Zafra-Gómez et al., 2009c). Measurement of this concept provides information about the entity's solvency or liquidity, that is, its ability to meet its obligations in the long term and the short term, respectively. Accordingly, the present financial analysis aims to determine the financial risks associated with local authorities' economic activities, by analysing their solvency.

Unlike financial position, the concept of financial condition addresses not only this facet of economic-financial information, but also others that influence the development of service delivery in municipalities, and which, even if they are not reflected in the analysis of financial position, have a tangible impact on the financial health of the local authority. However, the terms financial position and financial condition have sometimes been used in a confusing way, despite the Governmental Accounting Standards Board having clarified the broader nature of the concept of financial condition (paragraph 34 of Concept Statement 1), and different terms have been used to refer to the concept of financial condition, including fiscal crisis, fiscal stress, fiscal distress, fiscal emergency or financial condition (Honadle, 2003). Thus, the US State of Rhode Island uses the term "crisis", while Ohio speaks of "fiscal emergency", and Michigan and Pennsylvania, "fiscal distress".

In this context, the analysis of financial condition has been widely discussed (Hendrick, 1989; Greenberg and Hillier, 1995; Groves et al., 2003; Hendrick, 2004; Kloha et al., 2005a, 2005b; Wang et al., 2007; Zafra-Gómez et al., 2009a, 2009b, 2009c; Cohen et al., 2012) and the determinants of financial condition or fiscal distress have been studied from 
various perspectives, with different systems being proposed for measuring and evaluating the financial health of local authorities.

Among the different possibilities offered to measure this concept, for the purposes of the present study, we start with two that seem most appropriate. On the one hand, the proposal made by Groves et al. (2003), who pointed out that financial condition can be measured in terms of four inter-related factors: cash solvency, budgetary solvency, long-term solvency and service-level solvency. These authors defined cash solvency as the entity's ability to generate sufficient liquidity to meet its short-term obligations; budgetary solvency is its ability to obtain sufficient budget revenues, without provoking a budget deficit; long-term solvency concerns the government's ability to meet all its long-term liabilities; and service-level solvency is its ability to provide the level and quality of services necessary for the welfare of the community in question.

The second contribution considered was that of Greenberg and Hillier (1995) and CICA (1997), for whom financial condition can be measured through various indicators related to sustainability, flexibility and vulnerability. Sustainability is viewed as the ability of the entity to maintain, foster and preserve the social welfare of its citizens using the resources at its disposal. Flexibility is the entity's capacity to respond to changing economic and financial circumstances within the limits of its fiscal capacity; and vulnerability is its level of dependence on external funding to enable public spending levels to be maintained.

In the present study, the concept of financial condition is used to determine whether a municipality is in a position of financial stress, and the financial condition is assumed to include the following aspects: cash solvency, defined as the organisation's ability to generate sufficient liquidity to pay its short-term debts (Groves et al., 2003); flexibility, the organisation's capability to respond to changes in the economy or in its financial circumstances, via modifications to public debt (Greenberg and Hillier, 1995; CICA, 1997); budgetary sustainability (or service-level solvency), the organisation's ability to maintain, promote and protect the social welfare of the population, employing the resources at its disposal (Greenberg and Hillier, 1995; CICA, 1997; Groves et al., 2003; Hendrick, 2011); financial independence, the level of dependence on external funding received via transfers and grants (Berne, 1992; ICMA, 2003; Honadle, 2003; ZafraGómez et al., 2009a). Finally, we consider long-run solvency, using a broad time horizon for this study. All of these measures are set out in Table 1 and are evaluated using the set of indicators derived from budgetary and balance sheet information. 


\begin{tabular}{|c|c|c|c|}
\hline \multicolumn{2}{|c|}{$\begin{array}{l}\text { Elements of the Financial } \\
\text { Condition }\end{array}$} & Indicators & Definition \\
\hline \multirow{2}{*}{\multicolumn{2}{|c|}{ Short-run solvency }} & $\begin{array}{l}\text { Cash Surplus Index } \\
\text { (CSI) }\end{array}$ & $\begin{array}{l}\text { Difference between net } \\
\text { receivables, liquidity and not } \\
\text { liabilities }\end{array}$ \\
\hline & & Liquidity Index (LI) & Liquidity divided by net short-term liabilities \\
\hline \multirow{8}{*}{$\begin{array}{l}\text { Budgetary } \\
\text { solvency }\end{array}$} & \multirow[t]{2}{*}{ Flexibility } & $\begin{array}{l}\text { Net Savings Index } \\
\text { (NSI) }\end{array}$ & $\begin{array}{l}\text { Difference between the receivables from } \\
\text { current budget resources and the budget } \\
\text { obligations from non-financial current } \\
\text { expenditures, reduced by annual amortisation } \\
\text { payment-including interest and principal }\end{array}$ \\
\hline & & $\begin{array}{l}\text { Taxable value divided } \\
\text { by Financial Charge } \\
\text { Index (TVFCI) }\end{array}$ & $\begin{array}{l}\text { Taxable budgetary receivables divided by } \\
\text { annual amortisation payment - interest and } \\
\text { principal - }\end{array}$ \\
\hline & & $\begin{array}{l}\text { Weight of Budgetary } \\
\text { Receivables (TVCR) }\end{array}$ & $\begin{array}{l}\text { Taxable budgetary receivables divided by } \\
\text { annual current budgetary receivables }\end{array}$ \\
\hline & & $\begin{array}{l}\text { Sustainability of } \\
\text { Budgetary } \\
\text { Receivables (CETV) }\end{array}$ & $\begin{array}{l}\text { Current budgetary payables divided by } \\
\text { taxable budgetary receivables }\end{array}$ \\
\hline & & Debt & $\begin{array}{l}\text { Outstanding debt of the local authority and its } \\
\text { autonomous organisations, consortia and } \\
\text { associations }\end{array}$ \\
\hline & \multirow{2}{*}{ Independence } & $\begin{array}{l}\text { Index of Financial } \\
\text { Independence } \\
\text { (ITRANSF) }\end{array}$ & $\begin{array}{l}\text { Grants budgetary payables divided by total } \\
\text { budgetary payables. }\end{array}$ \\
\hline & & $\begin{array}{l}\text { Weight } \\
\text { Payables/Transfers } \\
(\text { TE/G) }\end{array}$ & Total budgetary payables divided by grants \\
\hline & Sustainability & $\begin{array}{l}\text { Non-Financial } \\
\text { Budgetary Result } \\
\text { Index (NFBRI) }\end{array}$ & $\begin{array}{l}\text { Current budgetary payables, non-financial } \\
\text { capital budgetary payables divided by non- } \\
\text { financial current budgetary receivables, non- } \\
\text { financial capital budgetary receivables. }\end{array}$ \\
\hline
\end{tabular}

Table 1. Elements of the financial condition

\section{Cooperate or outsource in response to fiscal stress?}

Outsourcing can be defined as a form of privatisation in which a private company obtains residual gains from service delivery (Vickers and Yarrow, 1988; Warner and Bel, 2008) and in this field it is the most important of the alternatives available (Pallesen, 2004). One of the economic factors promoting outsourcing is the impact of fiscal stress (tax burden, legal limitations on local tax levels and the size of transfers from central to local government) on local government. Bel and Fageda (2007) observed that one of the hypotheses most commonly analysed and empirically tested is that of the relationship between fiscal stress and outsourcing (Ferris, 1986; Miranda, 1994; Kodrzycki, 1998; Brown et al., 2008; Hebdon and Jalette, 2008) and various studies have concluded that local officials respond to fiscal problems by this means (Touche-Ross Company, 1987; Mouritzen and Nielsen, 1988; ICMA, 1989; Morgan and Hirlinger, 1991). 
Outsourcing is most commonly resorted to by larger municipalities, because smaller ones will often not have access to providers of the services required (Kodrzycki, 1998; Warner and Hefetz, 2003). As an alternative, municipalities can choose to join forces, via intermunicipal cooperation, to provide services that would be too costly for each one alone. Inter-municipal cooperation can reduce public sector spending, as the services provided under this form of management are consolidated via a single entity, whereas there may previously have been a larger number of entities and a higher level of total expenditure (Parks and Oakerson, 1993). In other words, it is hypothesised that small local authorities could employ inter-municipal cooperation to exploit economies of scale (Warner and Hefetz, 2003; Dijkgraaf et al., 2003; Warner, 2006a; Zullo, 2009). In addition, they would retain control of the service provided, which is not the case with outsourcing (Warner, 2006b). For these reasons, assuming that greater cooperation leads to lower spending and thus reduces fiscal stress for local government, there is a high probability that municipalities faced with fiscal stress will opt for the service to be provided in the form of inter-municipal cooperation.

\section{The effect of the great recession on the relationships between fiscal stress and outsourcing or inter-municipal cooperation}

As discussed in Section 2, numerous concepts have been proposed for evaluating the financial condition of public entities. However, events of the last decade may have changed how these concepts are viewed. As a result of the globalisation of the economy, events in localised areas can affect economic activity worldwide. This situation has given rise to the concept of crisis management. This concept was first developed in the private sector but in the present context can be readily transferred to the public sector. Crisis management can be clearly differentiated from the concepts of fiscal crisis, fiscal distress and financial condition. These latter are all part of what may be considered the economic and financial problems of a single entity, but crisis management refers to factors and events that influence the business activity of production units and which can also provoke major changes in organisational life (James and Wooten, 2010). These changes may be substantial and structural, and require public managers to adopt strategic responses to adapt the entity to the new circumstances.

For such a crisis to be present, there must exist a set of elements clearly differentiating it from other types of problems. First, a severe threat must be detected (Hermann, 1963), 
one that could significantly affect the aims of the organisation. The latter author noted that the concept of crisis also incorporates a certain element of surprise. But the entity must react appropriately both to the surprise and to the threat. This is what Hermann terms the short-term decision. Thus, a management crisis should present both these elements, although subsequently both the same author and Brady (1974) downplayed the importance of the element of surprise and of rapid decision taking. This concept of crisis could very well encompass the present Great Recession (GR). The GR has been characterised by its progressive appearance in different settings and the progressive decisions taken in response by different governments. The level of intensity of the crisis has varied among different countries, and the responses made by their governments have also differed. At present, and for the specific case of Europe, countries such as Portugal, Greece, Italy, Ireland and Spain are engaged in a whirlwind dismantling of the public sector, aimed at achieving total control of the public deficit.

This climate of change is also apparent at the local level, which is the object of most studies of financial condition, and thus any research in this field with an international focus, carried out since 2008, must take account of this situation characterising public sector finances in general and those of municipalities in particular. The first references to the situation of municipalities and their financial condition are the studies by LópezHernández et al. (2012) and Pérez-López et al. (2013), analysing the financial condition at the start of the period of crisis management. These studies have reported that the crisis affects different elements of the financial condition of local governments, to varying degrees. The element of financial condition that has undergone the most severe deterioration is that of budgetary sustainability, i.e., the control of the public deficit, which in turn has negatively impacted on budgetary stability. Secondly, the indicators of flexibility, that is, of government debt, have worsened. This latter element has been examined by the second group of authors (Pérez-López et al., 2013), who found that the variables which determine the level of debt, in the period from 2008 to 2011, presented certain differences from those identified in studies conducted during periods of economic stability.

These first studies in the Spanish context corroborate the need to consider the effects of crisis management in evaluating the financial condition of public bodies, particularly at the local level, and its relationship with the emergence of phenomena such as outsourcing and inter-municipal cooperation. The current economic and financial crisis may have altered the elements comprising financial condition and have pushed municipalities into 
outsourcing services or entering into processes of inter-municipal cooperation. Therefore, we propose the following hypotheses:

$\mathrm{H}_{1}$ : The elements of the financial condition affecting the outsourcing of public services differ between the pre-crisis period and during the Great Recession.

$\mathrm{H}_{2}$ : The elements of the financial condition affecting processes of inter-municipal cooperation for the provision of public services differ between the pre-crisis period and during the Great Recession.

\section{A study of local governments in Spain}

\subsection{Methodology and data}

In view of the characteristics of the data and the particular aims of this study, we decided to conduct a stepwise discriminant analysis (Sánchez-Fernández and Luque-Martínez, 2012). This analysis technique was applied for the following reasons:

- First, because the fundamental purpose of the study was to determine the relationship between behaviour (assessed by a dichotomous variable) and a set of financial indicators (expressed in terms of ten measurement metrics), under the assumption that these indicators may influence the behaviour. This configuration of variables makes the technique especially suitable and also enables us to evaluate the relative weight or importance of each value in characterising the behaviour.

- Second, having ten independent metrics makes it especially necessary to reduce the dimension of the problem and to develop a model containing the fewest possible independent variables. In this respect, the stepwise procedure for estimating discriminant functions allows us to obtain a model comprised exclusively of the independent variables that offer the greatest discrimination and prediction capacity, while removing potential redundancies among them.

The study sample was constituted of 1,572 local authorities in Spain, each with over 1,000 inhabitants, of the total of 3,106 such Spanish local authorities, for the period 2002-2010. Fiscal stress and economic, financial and budgetary data were obtained from the Directorate General for Financial Coordination with Regional and Local Authorities (DGCFCAEL). The number of inter-municipal cooperation processes was ascertained by consulting the general database of local entities, maintained by DGCFCAEL Finally, a 
purpose-built database was constructed by incorporating the announcements published by local authorities in Spanish official provincial gazettes regarding the outsourcing of certain services. Information about the descriptive statistics is given in Table 2.

\begin{tabular}{|l|l|l|l|l|l|}
\hline & $\mathrm{N}$ & Minimum & Maximum & Mean & Std. Deviation \\
\hline NSI & 14148 & -3.104772859 & 0.89351469 & 0.07 & 0.16 \\
\hline TVCR & 14148 & 0.042473713 & 0.964158577 & 0.58 & 0.15 \\
\hline NFBRI & 14148 & 0.310360754 & 3.495602817 & 1.02 & 0.17 \\
\hline TE/G & 14148 & 0.069991998 & 2.765167007 & 0.57 & 0.21 \\
\hline CSI & 14148 & -192.8107649 & 6564.840583 & 3.71 & 59.35 \\
\hline LI & 14148 & -90.87335352 & 6555.557724 & 2.34 & 58.91 \\
\hline TVFCI & 14148 & 0.206163572 & 51853.79258 & 33.43 & 615.93 \\
\hline CETV & 14148 & 0.090599958 & 5.330711451 & 0.69 & 0.27 \\
\hline Debt & 14148 & $0.00 \mathrm{E}+00$ & 6776856000 & 12798263.92 & 155579214.09 \\
\hline ITRANSF & 14148 & 0.044581194 & 0.947001888 & 0.46 & 0.16 \\
\hline
\end{tabular}

Table 2. Descriptive variables

\subsection{Results}

The first variable under analysis was outsourcing, and note was taken of the differences between the two groups defined by the dependent variable in relation to the measures for the ten values considered. However, not all the differences observed between the two groups were statistically significant. Thus, the last column in Table 3 shows that only 5 of the 10 variables revealed significant differences between the two groups.

\begin{tabular}{|l|c|c|c|l|c|c|c|}
\hline Variable & $\begin{array}{c}\text { Non-outsourcers: } \\
\text { mean value }\end{array}$ & $\begin{array}{c}\text { Outsourcers: } \\
\text { mean value }\end{array}$ & Total & Sign. & $\begin{array}{c}\text { Wilks' } \\
\text { Lambda }\end{array}$ & F & Sig. \\
\hline NSI & 0.07 & 0.07 & 0.07 & 0.440 & 1 & 0.596 & 0.440 \\
\hline TVCR & 0.57 & 0.63 & 0.58 & 0.000 & 0.984 & 222.734 & 0.000 \\
\hline NFBRI & 1.02 & 1.02 & 1.02 & 0.861 & 1 & 0.03 & 0.861 \\
\hline TE/G & 0.56 & 0.65 & 0.57 & 0.000 & 0.98 & 295.409 & 0.000 \\
\hline CSI & 3.73 & 3.56 & 3.71 & 0.914 & 1 & 0.012 & 0.914 \\
\hline LI & 2.36 & 2.16 & 2.34 & 0.896 & 1 & 0.017 & 0.896 \\
\hline TVFCI & 35.40 & 17.19 & 33.43 & 0.274 & 1 & 1.198 & 0.274 \\
\hline CETV & 0.68 & 0.74 & 0.69 & 0.000 & 0.995 & 72.808 & 0.000 \\
\hline Debt & 5433871.57 & 73266829.19 & 12798263.92 & 0.000 & 0.982 & 265.151 & 0.000 \\
\hline ITRANSF & 0.47 & 0.37 & 0.46 & 0.000 & 0.971 & 427.854 & 0.000 \\
\hline
\end{tabular}

Table 3. Equality of the means 
More specifically, it was found that the non-outsourcing group presents values that are higher and very different from those of the group that does outsource, with respect to the TVCFI variables and the short-term solvency ratios (CSI and LI). Moreover, the mean debt level of municipalities that outsource far exceeds that of the non-outsourcers, which corroborates the findings reported by Pérez-López et al. (2013).

In general, the existence of these significant differences between the two groups regarding these variables suggests it may be possible to develop an explanatory model to predict membership of these groups from the individual valuations for these variables.

Since the dependent variable divides the sample into two groups (non-outsourcing vs. outsourcing), discriminant analysis provides a single discriminant function that forms the basis for classification and prediction.

In this case, the discriminant function has a canonical correlation of 0.22 , indicating that the function has an average association with the dependent variable that it is intended to predict. However, the analyses carried out clearly reveal significant differences in the mean discriminant scores for the two groups (Wilks' Lambda $=0.952$, significance $=$ 0.000), which shows that this function has a certain discriminant capacity between the groups defined by the dependent variable.

The stepwise inclusion procedure resulted in the inclusion in the discriminant function of only four of the ten independent variables. The following table shows the values of the standardised coefficients of these variables in the discriminant function.

\begin{tabular}{|l|c|}
\hline Variable & Coefficient \\
\hline NFBRI & -0.089 \\
\hline CETV & 0.374 \\
\hline Debt & -0.574 \\
\hline ITRANSF & 0.999 \\
\hline
\end{tabular}

Table 4. Standardised coefficients of the discriminant function

From these values, we conclude that the four variables that make up the resulting model have unequal weights in shaping the discriminant function (between -0.089 and 0.999). Furthermore, these values allow us to anticipate that the discriminant function will clearly distinguish between municipalities with higher CETV, ITRANSF and NFBRI values. In other words, those with higher levels of current expenditure in relation to their tax 
revenues, those with higher costs of transfers to other entities and those with higher budget deficits are all more likely to outsource public services. For the debt variable, we find a similar situation. Decreases in municipal debt increase the likelihood of outsourcing taking place. This may be due to the fact that municipalities which outsource public services do not need to incur higher levels of debt, as they have already reduced spending by outsourcing their services (Pérez-López et al., 2013, 2014).

\begin{tabular}{|l|c|c|c|}
\hline \multirow{2}{*}{ Outsourcing } & Function & Pre-crisis function & GR function \\
\cline { 2 - 4 } & 1 & 1 & 1 \\
\hline 0 & 0.079 & 0.077 & 0.097 \\
\hline 1 & -0.646 & -0.739 & -0.608 \\
\hline \multicolumn{2}{|l|}{ Nonstandardised canonical discriminant functions evaluated at the mean values for the groups } \\
\hline
\end{tabular}

Table 5. Functions at the centroids of the groups

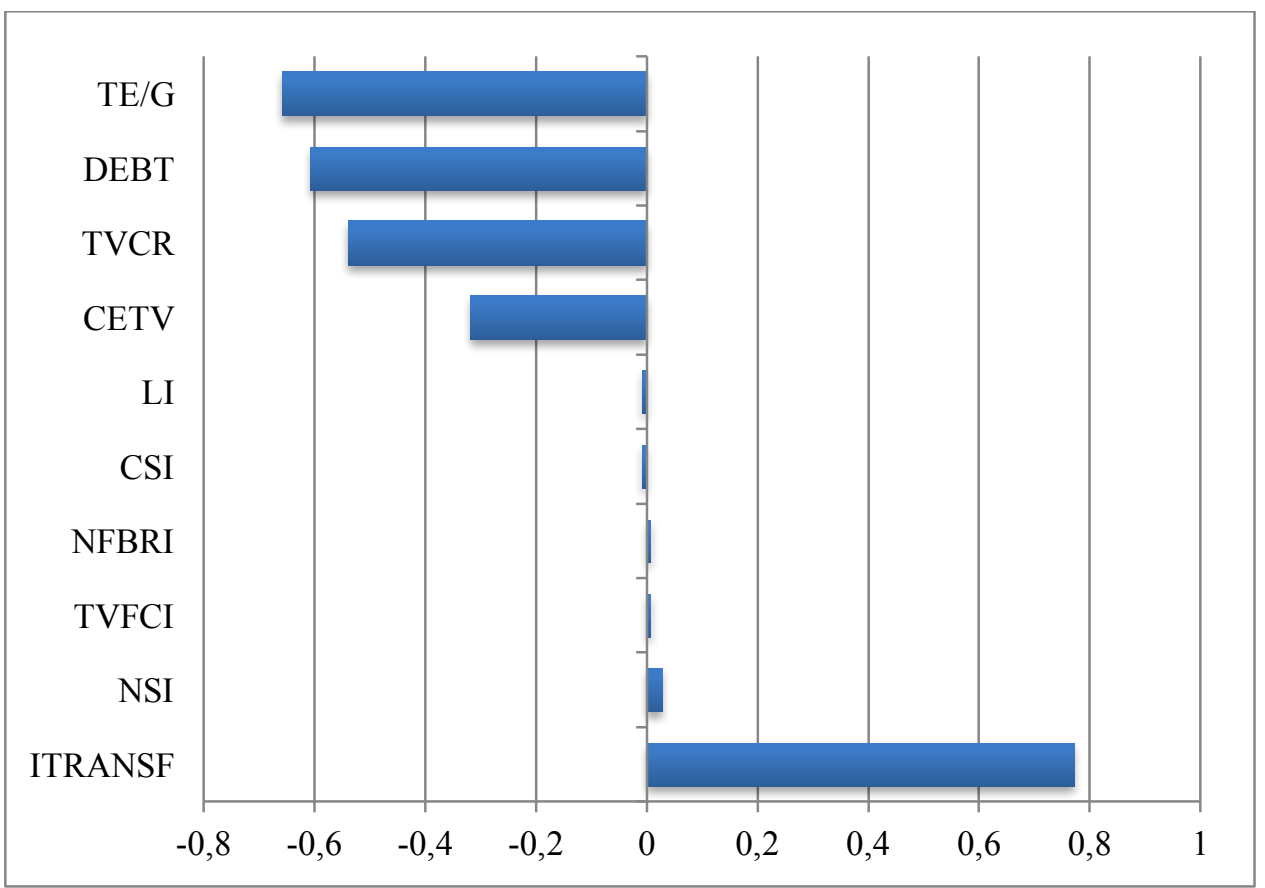

Figure 1. Correlations between the discriminant function and the independent variables (structure matrix)

Regarding the model's predictive capabilities, the results show that the discriminant function correctly predicts $64.2 \%$ of cases. In addition, for the non-outsourcing municipalities, this prediction rate is $64.2 \%$, very similar to the outsourcing group $(64.6 \%)$ (see Table 6). In general, however, this solution achieves a considerable 
improvement in the classification of cases, with a hit ratio that is higher than the percentage of cases that could be classified correctly by chance $(50 \%)$. Furthermore, Press's $Q$ statistic corroborates the predictive ability of the model $(\mathrm{Q}=1141)$.

\begin{tabular}{|l|r|r|r|r|}
\hline \multirow{2}{*}{ Count } & & $\mathbf{0}$ & $\mathbf{1}$ & \\
& 0 & 8091 & 4521 & 12612 \\
\cline { 2 - 5 } & 1 & 544 & 992 & 1536 \\
\hline$\%$ & 0 & 64.2 & 35.8 & 100 \\
\cline { 2 - 5 } & 1 & 35.4 & 64.6 & 100 \\
\hline
\end{tabular}

Table 6. Classification results

In view of the study aims, we were particularly interested in determining whether a similar explanation could be found for the behaviour of the dependent variable in the precrisis period (before 2008) in comparison to that for the GR (from 2008). Therefore, the discriminant analysis was repeated, obtaining the results discussed below.

With respect to the test for the equality of the means of the independent variables, the significant differences obtained previously were repeated in the same five variables as was the case for the combined sample group, for each of the two periods (see Table 7).

\begin{tabular}{|l|c|c|c|c|c|c|}
\hline \multirow{2}{*}{} & \multicolumn{3}{|c|}{ Pre-crisis } & \multicolumn{3}{c|}{ GR } \\
\cline { 2 - 7 } & Wilks' Lambda & F & Sign. & $\begin{array}{c}\text { Wilks' } \\
\text { Lambda }\end{array}$ & F & Sign. \\
\hline NSI & 1 & 1.169 & 0.280 & 1 & 0.858 & 0.354 \\
\hline TVCR & 0.985 & 142.315 & 0.000 & 0.979 & 101.542 & 0.000 \\
\hline NFBRI & 1 & 1.252 & 0.263 & 1 & 0.283 & 0.595 \\
\hline TE/G & 0.977 & 220.025 & 0.000 & 0.969 & 150.21 & 0.000 \\
\hline CSI & 1 & 0.001 & 0.978 & 1 & 1.926 & 0.165 \\
\hline LI & 1 & 0.001 & 0.979 & 1 & 1.71 & 0.191 \\
\hline TVFCI & 1 & 0.899 & 0.343 & 1 & 0.288 & 0.591 \\
\hline CETV & 0.994 & 54.068 & 0.000 & 0.991 & 42.136 & 0.000 \\
\hline Debt & 0.979 & 205.033 & 0.000 & 0.985 & 69.406 & 0.000 \\
\hline ITRANSF & 0.968 & 308.444 & 0.000 & 0.959 & 202.313 & 0.000 \\
\hline
\end{tabular}

Table 7. Equality of the means

Similarly, the same four variables were obtained as in the general case for the pre-crisis and GR periods, with similar weights, and with the same sign. 


\begin{tabular}{|l|c|c|}
\hline Variable & Pre-crisis & GR \\
\hline NFBRI & -0.128 & -0.161 \\
\hline CETV & 0.370 & 0.354 \\
\hline Debt & -0.591 & -0.455 \\
\hline ITRANSF & 0.984 & 1.073 \\
\hline
\end{tabular}

Table 8. Standardised coefficients of the discriminant function

For the pre-crisis period, the discriminant function presents a canonical correlation of 0.232 (Wilks' Lambda $=0.946$; significance $=0.000$ ), whereas for the GR, it is 0.236 (Wilks' Lambda $=0.944$, significance $=0.000$ ). Therefore, the discriminant functions are significant and their explanatory power is practically identical. In addition, the coefficients of the discriminant function are similar, and identical for the pre-crisis period and for the GR. We conclude, therefore, that the indicators which determine the fiscal stress-outsourcing relationship were not modified by the onset of the GR. This finding is corroborated by the fact that the percentage of correctly classified cases is also very similar, with $66.1 \%$ for the pre-crisis period and $63.3 \%$ for the GR.

Table 9:.

\begin{tabular}{|c|c|c|c|c|c|c|}
\hline & \multicolumn{2}{|c|}{ Total } & \multicolumn{2}{|c|}{ Pre-crisis } & \multicolumn{2}{|c|}{ GR } \\
\hline & 0 & 1 & 0 & 1 & 0 & 1 \\
\hline 0 & 8091 & 4521 & 5641 & 2902 & 2586 & 1483 \\
\hline 1 & 544 & 992 & 294 & 595 & 235 & 412 \\
\hline $0 \%$ & 64.2 & 35.8 & 66.0 & 34.0 & 63.6 & 36.4 \\
\hline $1 \%$ & 35.4 & 64.6 & 33.1 & 66.9 & 36.3 & 63.7 \\
\hline Hit Ratio & \multicolumn{2}{|c|}{$64.2 \%$} & \multicolumn{2}{|c|}{66.1} & \multicolumn{2}{|c|}{63.6} \\
\hline Q & \multicolumn{2}{|c|}{1141} & \multicolumn{2}{|c|}{979} & \multicolumn{2}{|c|}{347} \\
\hline
\end{tabular}

Table 9. Summary of case classifications

The second variable analysed was that of inter-municipal cooperation. This variable takes the value 1 when the local authority enters into cooperation with another or participates in a consortium, and the value 0 if it does not. The last column of Table 10 shows that for 8 of the 10 variables, there were significant differences between the two groups. 


\begin{tabular}{|l|c|c|c|c|c|c|c|}
\hline Variable & $\begin{array}{c}\text { No cooperation } \\
\text { group } \\
\text { Mean value }\end{array}$ & $\begin{array}{c}\text { Cooperation } \\
\text { group } \\
\text { Mean value }\end{array}$ & Total mean & Sign. & $\begin{array}{c}\text { Wilk } \\
\text { sam } \\
\text { bda }\end{array}$ & F & Sig. \\
\hline NSI & 0.073 & 0.078 & 0.074 & 0.272 & 1 & 1.207 & 0.272 \\
\hline TVCR & 0.572 & 0.620 & 0.576 & 0.000 & 0.991 & 129.051 & 0.000 \\
\hline NFBRI & 1.021 & 1.036 & 1.023 & 0.003 & 0.999 & 8.605 & 0.003 \\
\hline TE/G & 0.560 & 0.636 & 0.567 & 0.000 & 0.989 & 154.691 & 0.000 \\
\hline CSI & 2.966 & 11.117 & 3.714 & 0.000 & 0.998 & 22.282 & 0.000 \\
\hline LI & 1.614 & 9.539 & 2.342 & 0.000 & 0.998 & 21.38 & 0.000 \\
\hline TVFCI & 35.131 & 16.560 & 33.426 & 0.300 & 1 & 1.073 & 0.300 \\
\hline CETV & 0.681 & 0.751 & 0.687 & 0.000 & 0.994 & 80.167 & 0.000 \\
\hline Debt & 10862972.210 & 3194114.672 & 12798263.916 & 0.000 & 0.998 & 21.686 & 0.000 \\
\hline $\begin{array}{l}\text { ITRANS } \\
\text { F }\end{array}$ & 0.461 & 0.400 & 0.455 & 0.000 & 0.988 & 166.894 & 0.000 \\
\hline
\end{tabular}

Table 10. Equality of the means

The group of local authorities that entered into processes of inter-municipal cooperation presented different values from those obtained for the municipalities that outsourced public services. Our results show that the cooperating municipalities do not present worse levels of short-term solvency or of transfers and subsidies. On the other hand, they do have higher average levels of debt, although, as discussed below, this does not affect the value of the discriminant functions.

The discriminant function has a canonical correlation of 0.12 , indicating that the function does not present a very high association with the dependent variable that it is intended to predict. However, the results of the analyses clearly reveal significant differences in the mean discriminant scores of the two groups (Wilks' Lambda $=0.985$, significance $=$ 0.000), which shows that the function does have a certain capacity to discriminate between the groups defined by the dependent variable.

The stepwise inclusion procedure resulted in the inclusion in the discriminant function of only four of the ten independent variables. The following table shows the values of the standardised coefficients of these variables in the discriminant function.

\begin{tabular}{|l|c|}
\hline Variable & Coefficient \\
\hline NFBRI & -0.185 \\
\hline CSI & -0.317 \\
\hline Debt & 0.279 \\
\hline ITRANSF & 0.867 \\
\hline
\end{tabular}

Table 11. Standardised coefficients of the discriminant function 
From these values, we conclude that the four variables that make up the resulting model have unequal weights in shaping the discriminant function (between -0.317 and 0.867 ). Furthermore, we anticipate that the discriminant function will clearly distinguish between municipalities with higher values for transfers to other entities (ITRANSF) and for level of debt, on the one hand, and those which present negative values for budget deficit and cash solvency, on the other. On comparing these results with those obtained for the case of outsourcing, we see they are very similar, except for the exit of the CETV variable and the entry of CSI (short-term cash solvency) in the discriminant function. This latter aspect means that increases in short-term cash solvency make the municipality less likely to cooperate with others.

\begin{tabular}{|c|c|c|c|}
\hline \multirow{2}{*}{\begin{tabular}{c} 
Inter-municipal Cooperation \\
\cline { 2 - 4 }
\end{tabular}} & Function & $\begin{array}{c}\text { Pre-crisis } \\
\text { function }\end{array}$ & $\begin{array}{c}\text { GR } \\
\text { function }\end{array}$ \\
\cline { 2 - 4 } & 1 & 1 & 1 \\
\hline 1 & 0.039 & -0.042 & -0.019 \\
\hline Nonstandardised canonical discriminant functions evaluated at the mean values for the groups \\
\hline
\end{tabular}

Table 12. Functions at the centroids of the groups

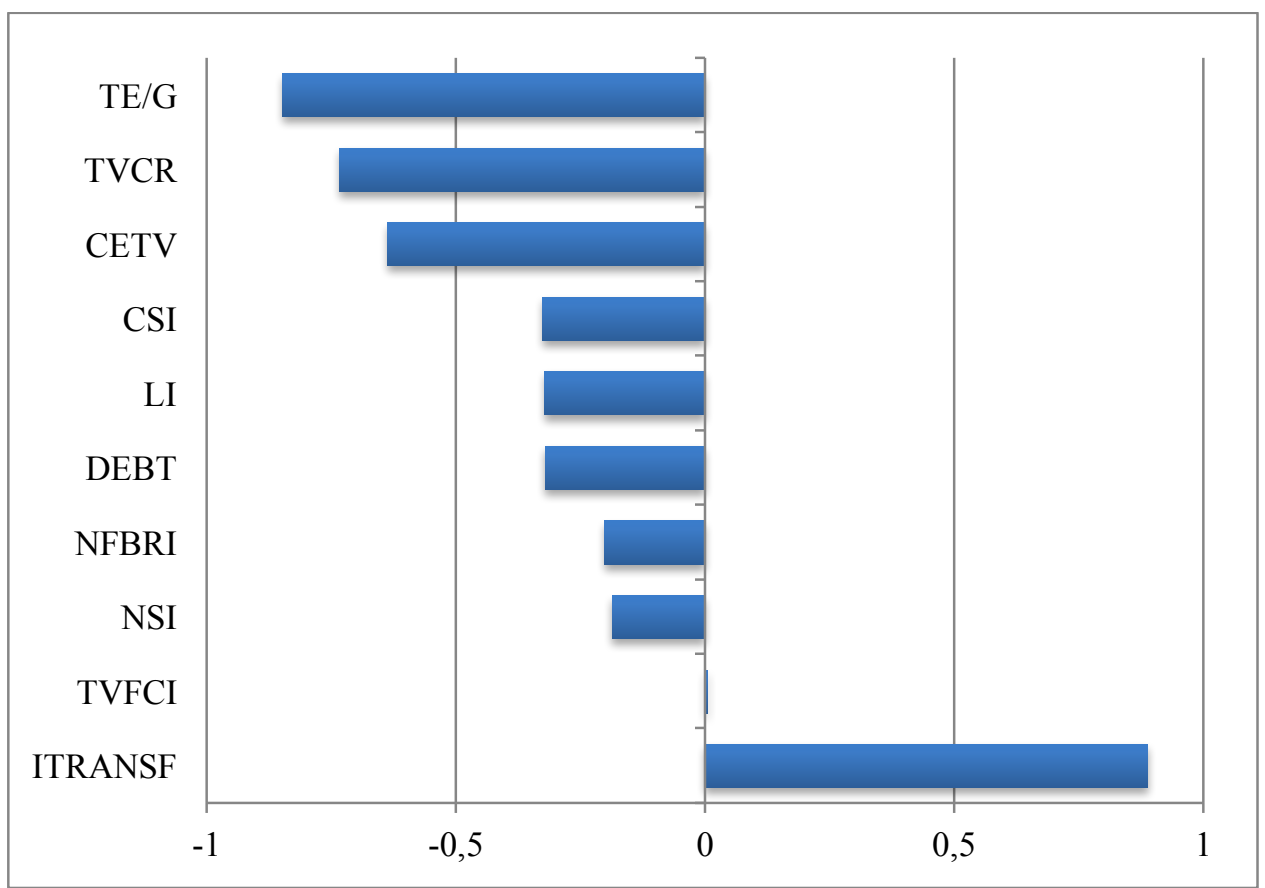

Figure 2. Correlations between the discriminant function and the independent variables (structure matrix)

Regarding the model's predictive capability, the results show that the discriminant function correctly predicts $57.9 \%$ of the cases. For the municipalities that do not 
cooperate, this predictive capability was 57.7\%, a similar value to that for the municipalities that do cooperate $(59.7 \%)$. Nevertheless, in general, this model obtains some improvement in the classification of cases, since the hit ratio is higher than the percentage of cases that could be classified correctly by chance $(50 \%)$. In addition, Press's $\mathrm{Q}$ statistic corroborates the predictive ability of the model $(\mathrm{Q}=356)$.

\begin{tabular}{|c|c|c|c|c|}
\hline & & $\mathbf{0}$ & $\mathbf{1}$ & \\
\hline Count & 0 & 7420 & 5429 & 12849 \\
\hline & 1 & 523 & 776 & 1299 \\
\hline$\%$ & 0 & 57.7 & 42.3 & 100 \\
\hline & 1 & 40.3 & 59.7 & 100 \\
\hline
\end{tabular}

Table 13. Classification results

The corresponding cluster analysis (pre-crisis vs. GR) produced the results discussed below.

With respect to the test for the equality of the means of the independent variables (see Table 14), the significant differences were not the same for the two periods in question. Indeed, there were also some differences with respect to the overall sample. Specifically, while in the pre-crisis period there were differences for all the variables except NSI, NFBRI and TVFCI, in the GR the differences in CSI and LI also ceased to be significant.

\begin{tabular}{|l|c|c|c|c|c|c|}
\hline \multirow{2}{*}{} & \multicolumn{3}{|c|}{ Pre-crisis } & \multicolumn{3}{c|}{ GR } \\
\cline { 2 - 7 } & Wilks' Lambda & F & Sign. & $\begin{array}{c}\text { Wilks' } \\
\text { Lambda }\end{array}$ & F & Sign. \\
\hline NSI & 1 & 0.666 & 0.415 & 1 & 0.133 & 0.715 \\
\hline TVCR & 0.991 & 81.236 & 0.000 & 0.994 & 27.602 & 0.000 \\
\hline NFBRI & 1 & 1.139 & 0.286 & 1 & 1.351 & 0.245 \\
\hline TE/G & 0.993 & 70.422 & 0.000 & 0.994 & 30.16 & 0.000 \\
\hline CSI & 0.998 & 15.977 & 0.000 & 1 & 0.012 & 0.913 \\
\hline LI & 0.998 & 15.378 & 0.000 & 1 & 0.041 & 0.840 \\
\hline TVFCI & 1 & 1.141 & 0.285 & 1 & 0.162 & 0.688 \\
\hline CETV & 0.996 & 39.017 & 0.000 & 0.998 & 10.223 & 0.001 \\
\hline Debt & 0.998 & 14.513 & 0.000 & 0.997 & 12.039 & 0.001 \\
\hline ITRANSF & 0.991 & 83.192 & 0.000 & 0.994 & 28.589 & 0.000 \\
\hline
\end{tabular}

Table 14. Equality of the means 
The discriminant functions are significantly different in the two time periods, mainly because in the GR, only TE/G and Debt form part of the discriminant function, and NSI, TVCR and CSI cease to have explanatory power, which means that there was a significant change from the pre-crisis period to the GR in the indicators that determine whether municipalities cooperate with each other.

\begin{tabular}{|l|c|c|}
\hline Variable & Pre-crisis & GR \\
\hline NSI & -0.291 & \\
\hline CETV & 0.529 & \\
\hline TE/G & 0.440 & 0.838 \\
\hline CSI & 0.347 & \\
\hline Debt & 0.315 & 0.502 \\
\hline
\end{tabular}

Table 15. Standardised coefficients of the discriminant function

For the pre-crisis period, the discriminant function obtained has a canonical correlation of 0.115 (Wilks' Lambda $=0.987$; significance $=0.000$ ), while for the GR it is 0.092 (Wilks' Lambda $=0.992$; significance $=0.000$ ). Therefore, the discriminant functions are significant and their explanatory power is practically identical. However, it should be noted that when the evaluation period is separated into two sub-periods, the elements of the financial condition that affect the cooperation process change significantly, with the variable that measures the budget deficit (NFBRI) and the index of transfers to other authorities (ITRANSF) being eliminated from the model. Replacing these variables, the model for the pre-crisis period introduces a variable that reflects the flexibility and sustainability of the current budget (NSI). When NSI is negative, the municipality is more likely to cooperate with other local entities. Also introduced is the TE/G variable, which measures the dependence of the local authority on grants in order to meet its expenses; when this variable increase, there is an increased probability of cooperation with other bodies. The third aspect introduced is the variable that reflects the entity's short-term solvency, although in this period it is positively related with inter-municipal cooperation, and so part of the fiscal stress-intermunicipal cooperation relationship is not accounted for by this variable. Finally, the outstanding debt variable for the pre-crisis period is positively related with cooperation processes, which implies that when debt rises, there 
is a greater likelihood of the municipality cooperating with others. This occurs because the local authority seeks to transfer debt to other instrumental entities, such as consortia or municipal associations, seeking to keep the debt value off the general account (PérezLópez et al., 2014). In other words, this mechanism is used as a means of debt avoidance ${ }^{1}$. Regarding the GR period, it should be noted that the debt variable has a similar effect to that observed for the pre-crisis period, together with the TE/G variable, and so both indicators are associated with an increased likelihood of inter-municipal cooperation. Finally, the percentage of correctly classified cases was significantly higher for the GR period $(63.6 \%)$ than for the pre-crisis period $(55.7 \%)$.

\begin{tabular}{|c|c|c|c|c|c|c|}
\hline & \multicolumn{2}{|c|}{ Total } & \multicolumn{2}{c|}{ Pre-crisis } & \multicolumn{2}{c|}{ GR } \\
\hline & 0 & 1 & 0 & 1 & 0 & 1 \\
\hline 0 & 7420 & 5429 & 4588 & 3738 & 2885 & 1638 \\
\hline 1 & 523 & 776 & 437 & 669 & 77 & 116 \\
\hline $0 \%$ & 57.7 & 42.3 & 55.1 & 44.9 & 63.8 & 36.2 \\
\hline $1 \%$ & 40.3 & 59.7 & 39.5 & 60.5 & 39.9 & 60.1 \\
\hline Hit Ratio & \multicolumn{3}{|c|}{57.9} & \multicolumn{2}{|c|}{55.7} & \multicolumn{3}{c|}{63.3} \\
\hline Q & \multicolumn{2}{|c|}{356} & \multicolumn{2}{c|}{124} & \multicolumn{3}{c}{} \\
\hline
\end{tabular}

Table 16. Case classification summary

\section{Discussion and conclusions}

Fiscal stress is one of the main variables included in models seeking to identify the factors that explain why municipalities outsource and enter into inter-municipal cooperation agreements for the provision of public services. However, no in-depth study has previously been made of this variable. According to several theories, the presence of a situation of fiscal stress may provoke changes in how municipal services are provided, in order to reduce costs and thus levels of fiscal stress. But what factors in the entity's financial condition induce it to carry out these changes? Previous studies have only considered the possibility of outsourcing, but there are others that municipalities could adopt in order to reduce the costs of their services. For this reason, we have broadened

\footnotetext{
${ }^{1}$ Article 36 of Royal Decree 1463/2007 obliges local authorities to inform the Bank of Spain of their outstanding debt, including that of consortia and associations in which they participate.
} 
the analysis, examining the impact of fiscal stress on management changes, not only regarding outsourcing to a private operator, but also addressing the question of intermunicipal cooperation. The results obtained show that when a set of financial indicators present values according to which municipalities are undergoing financial stress, these authorities will conduct operations to outsource public services and/or engage in cooperation with other municipalities. For both cases, the methodology applied in this study, that of discriminant analysis, obtained discriminant functions that were sufficiently precise to enable us to predict with a high degree of probability when a municipality will outsource services or enter into inter-municipal cooperation, in reaction to a state of fiscal stress. However, the elements that lead to these two outcomes vary slightly. While the variables that have the greatest impact on the outsourcing process are related to spending on transfers, budget sustainability and the flexibility of the entity, measured by its outstanding debt, cooperation processes are influenced, in addition to the latter factors, by the short-term solvency of the entity.

The division of the period of analysis into pre-crisis (2002-2007) and crisis (2008-2010) reveals differences in the behaviour pattern. While the GR did not alter the elements of the financial condition that lead municipalities to outsource services, there were significant changes with respect to processes of inter-municipal cooperation. On the other hand, in the pre-crisis period, questions of sustainability, flexibility and short-term solvency led municipalities to outsource their services, while during the GR, only debt and financial independence had a significant influence on cooperation decisions.

Another noteworthy finding is that the debt variable presented a different behaviour for the two responses: while it was negatively associated with outsourcing, the sign for cooperation was positive, because in the accounts item of outstanding debt municipalities are obliged to include the debt of the consortia or municipal associations in which they participate.

As a future line of research, we intend to analyse other forms of management open to local authorities in their aim to become more efficient and to overcome situations of fiscal stress. These forms include the creation of autonomous organisations and the provision of services by provincial councils. Finally, more complex analytic methods will be used, highlighting the strength and direction of relationships among the variables that may account for the level of outsourcing. To this end, and in view of the strong correlations between many of the financial indicators, we propose a preliminary factor analysis to 
identify specific factors that, after explaining and justifying their possible relations in terms of the corresponding theory, will allow us to use structural equation models based on a path-analysis method to explain the level of outsourcing and other forms of management. 


\section{REFERENCES}

Bel, G. and Fageda, X (2007). Why do local governments privatize public services? A survey of empirical studies. Local Government Studies, 33(4), 517-534.

Bel, G., Fageda, X. and Warner, M.E. (2010). Is private production of public services cheaper than public production? A meta-regression analysis of solid waste and water services. Journal of Policy Analysis and Management, 29(3), 553-577.

Berne, R. (1992). The Relationships between Financial Reporting and the Measurement of Financial Condition (Government Accounting Standard Board Research Report No. 18). Norwalk, CT: GASB.

Boyne, G.A. (1998). Bureaucratic theory meets reality: Public choice and service contracting in U.S. local government, Public Administration Review, 58(6), 474-484.

Brady, L.P. (1974). Threat, Decision Time, and Awareness: The Impact of Situational Variables on Foreign Policy Behavior (Unpublished Doctoral Dissertation). Ohio State University, Political Science Department.

Brown, T.L., Potoski, M. and Van Slyke, D.M. (2008). Changing modes of service delivery: How past choices structure future choices. Environment and Planning. Government and Policy, 26(1), 127-143.

Brudney, J., Fernandez, S., Ryu, J. and Wright, D. (2005). Exploring and explaining contracting out: Patters among the American States. Journal of Public Administration Research and Theory, 15(3), 393-419.

Canadian Institute of Chartered Accountants (CICA) (1997). Indicators of Government Financial Condition. Toronto, Ontario, Canada.

Christensen, T., Fimreite, A.L. and Lægreid, P. (2011). Crisis management: The perceptions of citizens and civil servants in Norway, Administration \& Society, 43(5), 561-594.

Cohen, S., Doumpos, M., Neofytou, E. and Zopounidis, C. (2012). Assessing financial distress where bankruptcy is not an option: An alternative approach for local municipalities. European Journal of Operational Research, 218(1), 270-279.

Dijkgraaf, E., Gradus, R.H.J.M. and Melenberg, B. (2003). Contracting out refuse collection. Empirical Economics, 28(3), 553-570.

Ferris, J. (1986). The decision to contract out: An empirical analysis. Urban Affairs Quarterly, 22(2), 289-311.

Greenberg, J. and Hillier, D. (1995). Indicators of Financial Condition for Governments. Paper presented at the 5th Conference of Comparative International Governmental Accounting Research, $4^{\text {th }}-5^{\text {th }}$ May, Paris-Amy, France. 
Greene, J.D. (2002). Cities and privatization: Prospects for the new century. Upper Saddle River, NJ: Prentice Hall.

Groves, M., Godsey, W. and Shulman, M. (2003). Evaluating Financial Condition: A Handbook of Local Government (3rd Ed.). Washington, DC: The International City/County Management Association.

Hebdon, R. and Jalette, P. (2008). The restructuring of municipal services: A CanadaUnited States comparison, Environment and Planning C: Government and Policy, 26(1), 144-158.

Hendrick, R. (1989). Top-down budgeting, fiscal stress and budgeting theory. The American Review of Public Administration, 19(1), 29-48.

Hendrick, R. (2004). Assessing and measuring the fiscal health of local government. Focus on Chicago suburban municipalities. Urban Affairs Review, 40(1), 78-114.

Hendrick, R. (2011). Managing the Fiscal Metropolis. The Financial Policies, Practices, and Health of Suburban Municipalities. Washington, DC: Georgetown University Press.

Hermann, C.F. (1963). Some consequences of crisis which limit of viability of organization. Administrative Science Quarterly, 8(1), 61-82.

Honadle, B.W. (2003). The states' role in U.S. local government fiscal crises: A theoretical model and results of a national survey. International Journal of Public Administration, 26(13), 1431-1472.

Hood, C. (1995). The "new public management" in the 1980s: Variations on a theme. Accounting, Organizations and Society, 20 (2/3), 93-109.

International City Management Association (ICMA) (1989). Service delivery in the 90s: Alternative Approaches for Local Governments. Washington, DC.

International City Management Association (ICMA)(2003). Evaluating Financial Condition: A Handbook for Local Government (fourth edition). Washington, DC.

James, E.H. and Wooten, L.P. (2006). Diversity crises: How firms manage discrimination lawsuits. Academy of Management Journal, 49(6), 1103-1118.

James, E.H. and Wooten, L.P. (2010). Leading under Pressure: From Surviving to Thriving Before, During, and After a Crisis. New York: Routledge Press.

Kloha, P., Weissert, C.S. and Kleine, R. (2005a). Developing and testing a composite model to predict local fiscal distress. Public Administration Review, 65(3), 313-323.

Kloha, P., Weissert, C.S. and Kleine, R. (2005b). Someone to watch over me. State monitoring of local fiscal conditions. The American Review of Public Administration, $35(3), 236-255$. 
Kodrzycki, Y. (1998). Fiscal pressures and the privatization of local services. New England Economic Review, pp. 39-50.

Levin, J. and Tadelis, S. (2005). Contracting for Government Services: Theory and Evidence from U.S. Cities. Stanford University, Mimeo.

López-Hernández, A.M., Zafra-Gómez, J.L. and Ortiz-Rodríguez, D. (2012). Effects of the crisis in Spanish municipalities' financial condition: An empirical evidence (20052008). International Journal of Critical Accounting, 4(5/6), 631-645.

Lorig, A.N. (1941). Determining the current financial position of a city. The Accounting Review, 16(1), 41-49.

Maitlis, S. and Sonenshein, S. (2010). Sensemaking in crisis and change: Inspiration and insights from Weick (1988). Journal of Management Studies, 47(3), 551-580.

Miranda, R. (1994). Explaining the privatization decision among local governments in the United States. Research in Urban Policy, 5, pp. 231-274.

Mohr, R., Deller, S.C. and Halstead, J.M. (2010). Alternative methods of service delivery in small and rural municipalities. Public Administration Review, 70(6), 894-905.

Moore, S. (1987). Contracting out: A painless alternative to the budget cutter's knife. Proceedings of the Academy of Political Science, 36(3), 60-73.

Morgan, D.R. and Hirlinger, M.W. (1991). Intergovernmental service contracts: A multivariate explanation. Urban Affairs Quarterly, 27(1), 128-144.

Mouritzen, P.E. and Nielsen, K.H. (1988). Handbook of Comparative Urban Fiscal Data. Odense, Denmark: Danish Data Archives.

Pallesen, T. (2004). A political perspective on contracting out: The politics of good times. Experiences from Danish local governments. Governance, 17(4), 573-587.

Parks, R.B. and Oakerson, R.J. (1993). Comparative metropolitan organization: Service production and governance structures in St Louis (Mo) and Allegheny County $(\mathrm{Pa})$. Publius, 23(1), 19-40.

Pérez-López, G., Plata-Díaz, A.M., Zafra-Gómez, J.L. and López-Hernández, A.M. (2013). Deuda viva municipal en un contexto de crisis económica: Análisis de los factores determinantes y de las formas de gestión. Revista de Contabilidad-Spanish Accounting Review, 16(2), 83-93.

Pérez-López, G., Plata-Díaz, A.M., Zafra-Gómez, J.L. and López-Hernández, A.M. (2014). Operaciones fuera de presupuesto (off budget), factores políticos y deuda municipal: Un estudio empírico aplicando una metodología de datos de panel. Gestión y Política Pública, 23 (1), 185-218.

Peters, B.G. (2011). Governance response to the fiscal crisis-comparative perspectives. Public Money and Management, 31(1), 75-80. 
Sánchez-Fernández, J. and Luque-Martínez, T. (2012). Análisis Discriminante. LuqueMartínez, T. (2nd Ed.). Técnicas de Análisis de Datos en Investigación de Mercados. Madrid: Pirámide.

Savas, E.S. (2000). Privatization and Public-Private Partnerships. New York: Chatham House Publishers.

Tiebout, C.M. (1956). A pure theory of local expenditures. Journal of Political Economy, 64(5), 416-424.

Touche-Ross Company (1987). Privatization in America.NY: Department of Commerce, Bureau of the Census (1988). County and City Data Book.

Vickers, J. and Yarrow, G. (1988). Privatization: An Economic Analysis. Cambridge, MA: MIT Press.

Wang, X., Dennis, L. and Sen, Y. (2007). Measuring financial condition: A study of U.S. States. Public Budgeting and Finance, 27(2), 1-21.

Warner, M.E. (2006a). Market-based governance and the challenge for rural governments: U.S. trends. Social Policy and Administration: An International Journal of Policy and Research, 40(6), 612-631.

Warner, M.E. (2006b). Inter-municipal cooperation in the U.S.: A regional governance solution? Urban Public Economics Review/Revista de Economía Pública Urbana, 7, pp. 132-151.

Warner, M.E. and Bel, G. (2008).Competition or monopoly? Comparing privatization of local public services in the US and Spain. Public Administration, 86(3), 723-735.

Warner, M.E. and Hefetz, A. (2003). Rural-urban differences in privatization: Limits to the competitive state. Environment and planning. C: Government and Policy, 21(5), 703718.

Zafra-Gómez, J.L., López-Hernández, A.M. and Hernández-Bastida, A. (2009ª). Developing a model to measure financial condition in local government: Evaluating service quality and minimizing the effects of the socioeconomic environment: An application to Spanish municipalities. American Review of Public Administration, 39(4), 425-449.

Zafra-Gómez, J.L., López-Hernández, A.M. and Hernández-Bastida, A. (2009b). Developing an alert system for local governments in financial stress. Public Money and Management, 29(3), 175-181.

Zafra-Gómez, J.L., López-Hernández, A.M. and Hernández-Bastida, A. (2009c). Evaluating financial performance in local government: Maximizing the benchmarking. International Review of Administrative Science, 75(1), 151-167. 
What elements of financial stress affect contracting out and intermunicipal cooperation in the provision of local public services? The impact of the great recession

Zullo, R. (2009). Does financial stress induce privatization? Correlates of private and intermunicipal contracting, 1992-2002.Governance: An International Journal of Policy, 22(3), 459-481. 